\title{
"DESMAYARSE, ATREVERSE, ESTAR FURIOSO...". LA REPRESENTACIÓN DEL AMOR Y EL MATRIMONIO EN LA PINTURA ESPAÑOLA DEL RENACIMIENTO Y BARROCO ${ }^{1}$
}

\author{
Rosa Elena Ríos Lloret \\ Universitat de València
}

\begin{abstract}
Resumen: Durante los siglos XVI y XVII, la Monarquía y la Iglesia españolas establecieron unas normas de control de la población que incluían también el gobierno de las emociones. Para imponer su dominio sobre espacios tan íntimos como los del deseo y el amor, la pintura fue un vehículo eficaz. El objetivo del presente trabajo es el de reflexionar, no sólo acerca del modo en el que las imágenes pintadas ${ }^{2}$ colaboraron al relato de la construcción de las conductas en el ámbito de los afectos, sino también cómo en estas representaciones se entrevén las discrepancias y los desacuerdos.
\end{abstract}

Palabras clave: Emociones, Amor, Matrimonio, Pintura Esañola, Representación, Renacimiento, Barroco.

The representation of love and marriage in the Spanish paintings in the Renaissance and the Baroque period. "Desmayarse, atreverse, estar furioso..." (Lope de Vega)

Abstract: The Monarchy and the Church in Spain set some control rules for its population in the $16^{\text {th }}$ and $17^{\text {th }}$ centuries, including how to rule emotions. They used paintings as a tool to manage such intimate spaces as those of desire and love. This paper is a reflection not only on how painted images contributed to the narrative of the construction of behaviours within feelings, but also on the disagreements that these representations also convey.

Key words: Emotions, Love, Marriage, Esañola Painting, Representation, Renaissance, Baroque.

\section{INTRODUCCIÓN}

Buscar respuestas a la pregunta de cómo fue la representación del amor y del matrimonio en la pintura española del Renacimiento y Barroco no es una cuestión exclusiva de la Historia del Arte, porque la pintura también es una fuente documental que permite un modelo de hacer historia que tiene que ver con las prácticas culturales. Siguiendo a Chartier (2002), se trata de la cultura que construye lo social en referencia al modo en que esas prácticas culturales definen, articulan o interpretan a los individuos, sus relaciones y com-

Data de recepció: 23 de juliol de 2014 / Data d'acceptació: 9 de febrer de 2015.

${ }^{1}$ Este trabajo se incluye dentro de un proyecto de investigación adscrito al Departamento de Historia Moderna de la Universitat de València, titulado "El proceso civilizador y la cuestión de los individuos. Normas, prácticas y subjetividades (siglos XVII-XIX)". Referencia HAR2011-26129.

${ }_{2}$ Es preciso aclarar que, en este trabajo, sólo se van a utilizar las imágenes de los cuadros, por lo que los grabados quedan excluidos de él. 
portamientos, y a las propias instituciones que los dirigen, legislan y organizan. Cuando se habla de representación, se establece una relación con lo real, pero esta relación no implica una coincidencia absoluta. La representación es otro modo de acercarse a la realidad, porque pretende influir en ella y construirla; ¿y qué mejor forma de representación que la pintura? Es de sobra conocido que la pintura es el resultado de la pericia y el empeño del artista, aunque éste no tenga una absoluta libertad de acción, porque también es el producto del gusto de los clientes que hacen el encargo. Sin embargo, ese anhelo de los comitentes tampoco se muestra siempre de forma explícita. Conviene subrayar que las imágenes pintadas también son el resultado de lo que la moral social considera que debe ser lo permitido y permisible, lo que desde el poder se piensa que se debe desear, y esta circunstancia no es en absoluto desdeñable. En la España de los siglos XVI y XVII, la Monarquía y la Iglesia instauraron un modelo cultural que defendiera y sustentara la ideología de un gobierno compartido, y pronto comprendieron la importancia de las imágenes en la construcción de este modelo. Así, los teólogos tridentinos orientaron, diseñaron e intervinieron en la producción artística para dirigir la ideología de los fieles y evitar la heterodoxia, pero también para modelar las mentalidades y ordenar las emociones según sus leyes, y ese afán vigilante recayó sobre la pintura con un celo notable, por lo que a lo largo de estos siglos, la pintura española soportará un control y una censura mucho más exigentes que los del resto de Europa, y mucho más severos incluso que los que se ejercieron sobre la literatura. Ese afán por vigilar y custodiar las imágenes se debe a que desde antiguo existía el sentimiento de la enorme influencia de la representación pintada sobre la vida y conducta de las personas (Freedberg, 1999), idea ésta que perdurará hasta los siglos que aquí nos ocupan ${ }^{3}$. Será en estos años cuando aparezca una teoría artística que giraba en torno a la idea de la "imagen útil” (Portús, 1999, p. 22), según la cual la pintura se acreditaba como el medio ideal para difundir normas de conducta y modelos de comportamiento, tanto para las minorías dirigentes como para las masas analfabetas. Así pues, la necesidad de supervisar las imágenes deriva del hecho, considerado incuestionable, del enorme influjo que ejercían sobre el espectador, y esa ascendencia la debían administrar Iglesia y Monarquía, y no sólo para cumplir unos ideales de moral cristianos, sino para lo que Burke (1998) denomina "valor", que para él tiene un sentido más amplio que el de "moral", pues ésta se ciñe a unos preceptos éticos, mientras que en el concepto de valor intuye una normativa que se refiere también a unas pautas sociales. De la autoridad que se le otorgó a las imágenes sirva como ejemplo la tratadística con la que, a partir de la Contrarreforma, los teólogos y religiosos de este tiempo nutrieron los anaqueles de las bibliotecas. Aunque Italia fue la principal divulgadora de este tipo de tratados en los que se insiste en el destacado papel del artista en la tarea de educar y adoctrinar, no fue menos importante la aportación española, como la del jesuita Jerónimo Nadal Evangelicae Historiae Imagines (1593), los Diálogos del pintor cristiano (c. 1607) de fray Diego de Arce o el de sobra conocido Arte de la Pintura, su antigüedad y grandezas (1649), de Francisco Pacheco, seguidor de las ideas de Molano y Paleotti. Sin embargo, y a pesar de todos los esfuerzos, existirán grietas en ese constructo en apariencia tan sólido. Resquicios por los que se muestra un tiempo no tan ordenado como en una primera mirada se pudiera pensar.

\footnotetext{
${ }^{3}$ En la comedia de Lope de Vega La quinta de Florencia, el protagonista adorna su casa con pinturas cuyo poder seductor lo enardece de tal manera, que lo lleva hasta la violación.
} 
Fig. 1. Diego de Silva y Velázquez (atri.). Retrato del bufón "Calabacillas", 1626-1630. Museo de Cleveland.

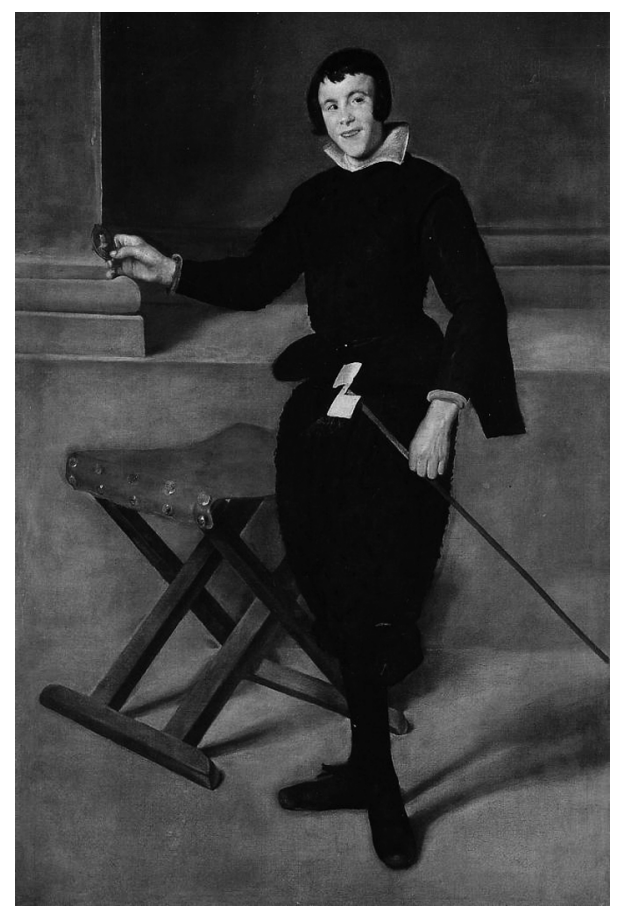

\section{DESMAYARSE, ATREVERSE, ESTAR FURIOSO...}

Cuando se consultan los diversos estudios acerca del amor, el deseo y la sexualidad españolas durante los siglos XVI y XVII, se observa que frente a la ortodoxia normativa, existía un comportamiento no siempre obediente que transgredía las reglas de castidad y pureza socialmente exigidas, tan repetidas en los tratados morales, tratados que serán numerosos, lo que puede ser indicio de realidades no tan constreñidas. De hecho, en uno de ellos, el Tratado del Amor a Dios (1621), de Cristóbal de Fonseca, se habla del poder de la pasión amorosa que rompe con todas las ataduras y afecta a todos los miembros de la escala social. Barraganía, concubinato, amancebamiento, bigamia y otras situaciones anómalas eran relativamente comunes en la España del Renacimiento y Barroco y, aunque muchas de estas circunstancias son argumentos literarios, en la pintura no hay cuadros que se puedan comparar con las tramas de los textos. Por tanto, ejemplos de este tipo de lienzos son escasos en este trabajo, porque exigua es la producción de este género pictórico en el caso español. En cambio, no son extrañas las obras de ficción en las que se presentan amores ardientes, contrariados o imposibles; historias que tienen al deseo y a la pasión como protagonistas, como el poema de Lope de Vega que sirve de encabezado. Sin embargo, no se observa algo tan alborotado en la pintura española. Se llegó a crear un género literario, el de la novela cortesana, que trataba estos argumentos y que tenía un público lector femenino, pero también unas autoras destacables, como María de Zayas, 
Leonor Meneses o Mariana de Carvajal, en cambio, la permisividad y la autoría femeninas no aparecen en la pintura. La pintura era obra hecha por hombres, y casi siempre, excepto la de género religioso, para clientes masculinos. Eran ellos los autores de un relato que construía un modelo jánico de mujer, basado en el principio de la inferioridad espiritual femenina, en su materialidad y en su calidad no sólo de pecadora, sino también de atraer al hombre al mal. Por ello, si, como se ha señalado, existía la convicción de que la visión de escenas amorosas, incluso sólo la de la amada ${ }^{4}$, tenía sobre el espectador un efecto tan extraordinario, parece natural su censura, porque esa conmoción otorgaba un poder aborrecible a la mujer.

En el arte nacional, la representación del amor humano implica su condición amenazadora y embustera, creación del diablo. Un ejemplo es la obra de El Greco Fábula (1580). En el centro de la composición, una mujer tiene en una mano un tizón al que sopla para prender una candela que sostiene con la otra. Tras ella, asoma un mono ${ }^{5}$, que contribuye a avivar la llama y, al otro lado, un hombre riendo, tocado de una gorra de color rojo. Aunque hay diversas hipótesis sobre la interpretación iconográfica de esta obra, sigue siendo muy interesante la de Cossío (1908), que aludió al carácter picaresco de la escena y recordó el proverbio español: "El hombre es fuego, la mujer estopa, viene el diablo (el mono) y sopla”. Hay aquí una lección moral que enseña a ser precavido ante las acechanzas del deseo, y esa cautela no siempre aparece en la pintura europea, que, la mayoría de las veces, se limita a representar la pasión amorosa, sin que sea necesario aleccionar de sus consecuencias al público que la mira. En la pintura española, la pasión es sospechosa porque desordena; tal vez por ello, se usará la vieja estrategia medieval de ridiculizar aquello que se pretende erradicar. Aunque existen textos que tratan con desdén el amor humano, la pintura es más radical, porque si aparece en los lienzos, lo hace revestido de una mirada irónica ante esa enajenación amorosa. En una obra atribuida a Velázquez, Retrato del bufón Juan Calabazas, "Calabacillas”, 1626-1630, el artista muestra a esta sabandija de palacio que sostiene una miniatura de una dama, tal y como solían llevar los caballeros de la época, dama por la que se sentía cautivado, con gran regocijo de la Corte. Aquí, Velázquez desdibuja al galán enamorado en la figura de este pobre hombre de placer palaciego. Esa pasión resulta estrafalaria viniendo de quien viene y hacia quien va dirigida, aunque también tiene otra lectura: la de parodiar emociones cuya exageración las convierte en poco dignas para el que las experimenta y para quien las acoge, tal vez porque lo que es poco noble es dejarse llevar por ellas, que no son merecedoras de tanto desasosiego. En efecto, durante el siglo XVII, el deseo amoroso se presenta en la pintura española como algo rechazable por su condición de pecado, pero también porque, como se ha dicho, esa pasión convierte al hombre en un juguete en manos de la mujer, que deja de ser la obediente y sumisa reclamada ya por Vives, y se convierte en la poderosa reina servida por el amante/esclavo. Dos pequeños cuadros de Diego López, "el mudo", de la segunda mitad

${ }^{4}$ Lluís del Milá hará exclamar a uno de los personajes de El Cortesano, ante una pintura de una dama a la que sirve: "Mas te quiero yo pintada que a mi muger biva, pues tu me desenojas en mirarte y mi muger me enoja en mirarme. Ella de braveza me mata y tu de benina me resucitas" (Milà, 1561, ed. de Escartí y Tordera, 2001, pp. 177-178).

5 El mono es famoso por su gusto por la imitación. Esto sirvió para considerarlo símbolo demoníaco, porque el diablo trata de imitar las cosas de Dios. Simboliza también los bajos instintos, la sensualidad y los vicios en general. 


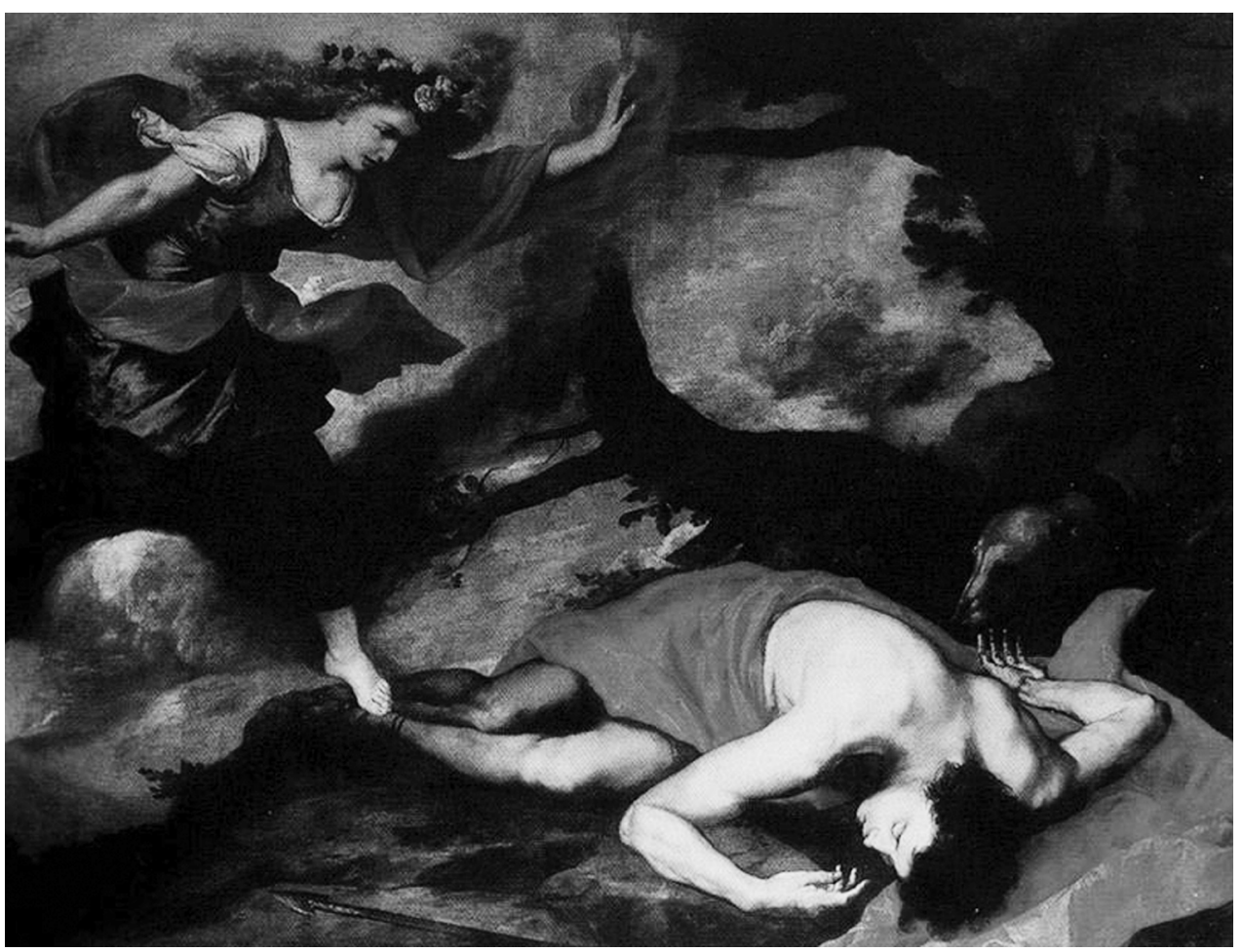

Fig. 2. José de Ribera. Venus y Adonis, 1637. Palacio Corsini, Roma.

del siglo XVII, presentan una rara iconografía en nuestra pintura. En ellos, un motivo mitológico y otro bíblico, Hércules y Onfalia y Sansón y Dalila, muestran la sumisión masculina frente a la triunfante fortaleza de la mujer. Esa suspicacia de la pintura ante el poder de la hermosura femenina la ilustra el lienzo, también de la segunda mitad del siglo XVII, de Pedro de Camprobín, La muerte y el caballero. Obra cercana al género de vanitas, en él aparece un joven que se descubre ante una tapada ${ }^{6}$ que deja entrever un bello rostro, pero también su calavera. Aunque se pueda explicar como la imprevista llegada de la Muerte, es significativo que ésta aparezca con unos bellos pero engañosos rasgos femeninos. Esa condición embustera del amor de la mujer quizá aclare el sentido de las obras que narran cómo los santos o el hombre bueno rechazan las tentaciones, como en la obra de Velázquez La tentación de santo Tomás de Aquino (c. 1632). Es muy significativo que esa tentación sea siempre la de la carne y que estos piadosos varones se vean perturbados por mujeres que los intentan cautivar. Lo mismo ocurre en el pasaje del Antiguo Testa-

${ }^{6}$ Conviene recordar que las "tapadas" eran con frecuencia, prostitutas callejeras en busca de clientes. La relación con la enfermedad del cuerpo y del espíritu que transmite la mujer del cuadro es evidente. 
mento del casto José. Murillo tiene dos versiones, una de 1640-1645 y otra de 1660, muy interesantes las dos porque, aunque José huye espantado de los encantos de la mujer de Putifar, ésta aparece semidesnuda en el lecho. Hasta tal punto son peligrosas esas imágenes de mujeres sometiendo al varón por la fuerza del deseo, que son extrañas, por no decir casi inexistentes, las representaciones de la Judith bíblica ${ }^{7}$, que llegará a ser intercambia-

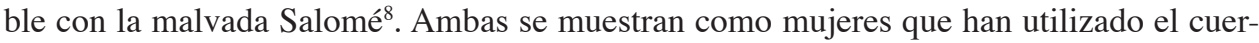
po para destruir al varón, que se ha dejado llevar por los sentidos. No parece, pues, que fuera un argumento deseado por los censores. Demasiada belleza. Demasiado poder. De hecho, en España nunca aparece Judith en el acto de matar a Holofernes. Por lo que se refiere a Salomé, Carreño de Miranda la pintará en El festín de Herodes (1656), y Valdés Leal, en La danza de Salomé (1676). En estas dos obras hay un discurso moral latente: la buena comida, la bebida abundante, la música y el baile predisponen a excesos lascivos de consecuencias fatídicas. Con todo, la imagen no debía aguijonear los apetitos de los posibles espectadores, por esto esas cautivadoras hechiceras debían reprimir sus encantos y se las solía pintar vestidas. De este modo aparecen las seductoras en la obra de Zurbarán Las tentaciones de san Jerónimo (1639), o las de Valdés Leal en la obra del mismo título de 1657. Tal vez por todo ello son tan pocas las obras, incluso las de tema religioso, que pudieran exigir la imagen de una mujer hermosa desnuda o semidesnuda ${ }^{9}$. Adán y Eva son casi inexistentes en la pintura española del XVI y XVII ${ }^{10}$, como también escasean los cuadros cuya protagonista es una santa, joven y bella que, sometida a un terrible martirio, debe mostrar su cuerpo atormentado, como El martirio de santa Águeda (1578), de Gaspar de Palencia. Un caso especial es el de María Magdalena, una mujer que encarnaba a todas las mujeres, porque todas eran malas por naturaleza y a todas convenían el arrepentimiento, la mortificación y la enmienda. Sin embargo, aun penitente y cubierta con harapos, se admira su cuerpo perfecto y, aunque su desnudez pueda tener una explicación moral, solo justificada por su arrepentimiento, María Magdalena se muestra siempre atractiva y sugerente ${ }^{11}$, incluso en los cuadros de altar.

Este control de imágenes femeninas fascinadoras se ejerció también sobre algunas mujeres de la Biblia, como Betsabé o Susana, protagonistas en cambio de muchas obras en la pintura europea, difíciles de encontrar en la pintura española, aunque sí que son, sobre todo Susana, heroínas literarias (Walthaus, 2004). Ambas son objeto del deseo de David o de los viejos al observarlas bañándose, ambas seductoras inocentes, pero al cabo, seductoras. Aunque ignoran que están siendo espiadas, el artista desvanece el origen moral de su figura, para mostrarlas como mujeres que al acicalarse, aún sin pretenderlo, incitan a los hombres a pecar. Quizá esa sea la causa de su escasez en España, no sólo porque una mujer bañándose exigía un cuerpo desnudo y atractivo para provocar la lubricidad, y

7 Una de las pocas es la obra de Juan de Pareja, Judith (1630-1670), en la que aparecen la heroína y su criada llevando en un saco la cabeza de Holofernes.

${ }^{8}$ Del siglo XVI, hay una Salomé de Pedro de Berruguete llevando la cabeza del Bautista en una bandeja. Del siglo XVII, la de Juan Bautista Maíno, siguiendo la misma iconografía.

9 Uno de los pocos ejemplos es el Descenso al limbo (1640), de Alonso Cano, en el que el hombre y la mujer del cuadro aparecen desnudos.

${ }^{10}$ Uno de los pocos ejemplos podría ser la creación de Eva que forma parte del retablo de san Miguel, de Joan de Joanes, actualmente en la Iglesia de san Nicolás y san Pedro Mártir de Valencia.

11 El número limitado de páginas hace imposible un estudio detallado sobre las imágenes de la Magdalena. 


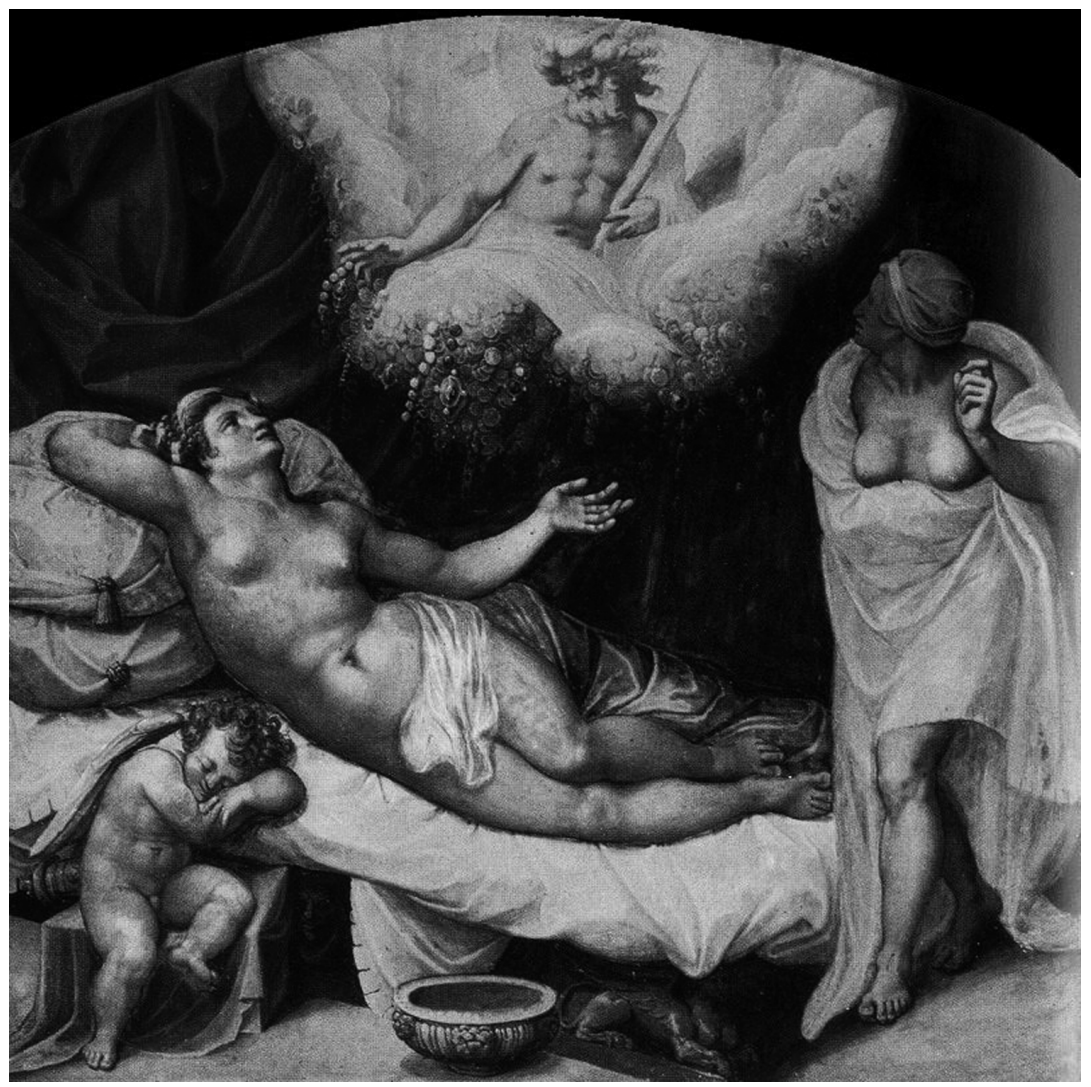

Fig. 3. Gaspar Becerra. Dánae, c. 1569. Panel del techo del aposento de la Camarera, Palacio del Pardo, Madrid.

eso podría ser tentador para el espectador, sino también porque mostraba el dominio femenino mediante la manipulación del deseo masculino. Así pues, las autoridades no sólo controlaron las imágenes religiosas para evitar heterodoxias y herejías, sino que se esforzaron en prohibir las llamadas "pinturas lascivas", apelativo que se dio a las que mostraban desnudos femeninos y a las que incitaban a la lujuria por el argumento representado, por lo que se prohibirá su creación e importación, aunque no siempre se cumplirá tal ley, como lo demuestran los índices inquisitoriales (Rodríguez de Ceballos, 1984). El veto para la realización de estas obras se puede explicar como una forma de evitar el pecado en el que podrían caer quienes las contemplaran, pero también, y no menos importante, como forma de controlar los deseos individuales y construir un modelo de sentimentalidad rígido y pautado por el poder. La demonización de la sexualidad femenina cuando no está vinculada exclusivamente a la maternidad y la sumisión propias de la esposa/madre, será 
el resultado de la actitud negativa de las autoridades eclesiásticas, que convierte a algunas de estas figuras seductoras en personajes cuyo poder solo se explica por la intervención del diablo. El germen de las pinturas lascivas procedía, en gran parte, de las historias amorosas de la mitología clásica. Más frecuente de lo que se supone, la mitología en la pintura española aparece como metáfora de la historia de España, como ejemplo heroico, como imagen del poder o incluso como emblema moral de comportamiento (López Torrijos, 1995). En cambio, por lo que se refiere al amor, la situación es otra. En la España de estos siglos, cuya cultura estaba fundamentalmente dominada por la Iglesia, era muy difícil que pudieran pasar la criba censoria las aventuras de una diosa como Venus, y eso a pesar de los intentos moralizantes con los que se justificaba su presencia. Ribera la pintará, pasmada y aterrada ante Adonis muerto, en un lienzo que permite disfrutar del argumento del cuadro al espectador preparado que conoce la historia, pero que, para un público ignorante, no supone ninguna tentación peligrosa, ya que la diosa está vestida, coronada de rosas, y se muestra como una mujer enamorada trastornada ante el cadáver de su amante ${ }^{12}$. Porque el riesgo estaba en la representación de la desnudez, sobre todo de la desnudez femenina. Ese cuerpo que había sido alegoría de tantas ideas sublimes para la filosofía neoplatónica y humanista, era ahora una amenaza carnal que conducía al pecado. Tratadistas como Francisco Pacheco o José García Hidalgo rechazan que estos temas tengan dignidad y niegan licencia para que se reproduzcan. Y sin embargo, sí que se pintaron. Artistas extranjeros, como Tiziano y Rubens, por señalar los más conocidos, cumplieron con demandas de clientes españoles, y pintores patrios también realizaron, por encargo, obras con este tipo de temática, la más famosa la Venus del espejo (1647-51), de Velázquez. Así pues, este trayecto conduce a los comitentes, a los coleccionistas de estos cuadros (Morán y Checa, 1985), que van a ser la monarquía y la nobleza (Urquízar, 2007). En el palacio de El Pardo se encontraban algunas de las obras maestras de la colección de Felipe II, las "Poesías", que Tiziano realizó para él entre 1552 y 1563. Años más tarde, la llegada de Rubens a España permitirá a Felipe IV encargarle toda una serie de obras con este tipo de temas. Después de la monarquía, será la nobleza la que seguirá la senda marcada por el rey y se convertirá en solicitante de este género pictórico en el que el desnudo, un desnudo erótico o que cuenta una historia de este tipo, pero escudado en la mitología, se convierte en el argumento principal. Por lo tanto, a pesar de las prohibiciones y de los discursos, en apariencia inflexibles, la discrepancia se cuela por estos resquicios. Eso sí, estas obras se encontraban en cámaras cuyo acceso era muy restringido, porque el control se ejercía sobre todas las capas sociales, incluidas las más elevadas.

En el Laberinto de Amor de Cervantes, el autor pone en boca de uno de los personajes los siguientes versos: “¿Pues de qué te maravillas? / Di: ¿no puede acontecer, / sin admiración que asombre, / que una mujer busque a un hombre, / como un hombre a una mujer?" (Cervantes, 2009, p. 59). Este derecho del deseo compartido no tiene un equivalente pictórico. En la pintura, el deseo femenino es censurable porque es propio de mujeres sueltas, desordenadas y prostitutas, por lo tanto no es conveniente representarlo. Es más, las imágenes de la prostitución son muy raras y discretas en la pintura española. Tal vez sea Murillo de los pocos pintores españoles que haya tratado este tema, pero siempre de una forma muy ambigua y decorosa, porque aparentemente son sólo muchachas del pueblo llano, aun-

12 Con todo, existe otra versión, actualmente en el Museo de Cleveland, en la que la diosa aparece con el pecho descubierto. 


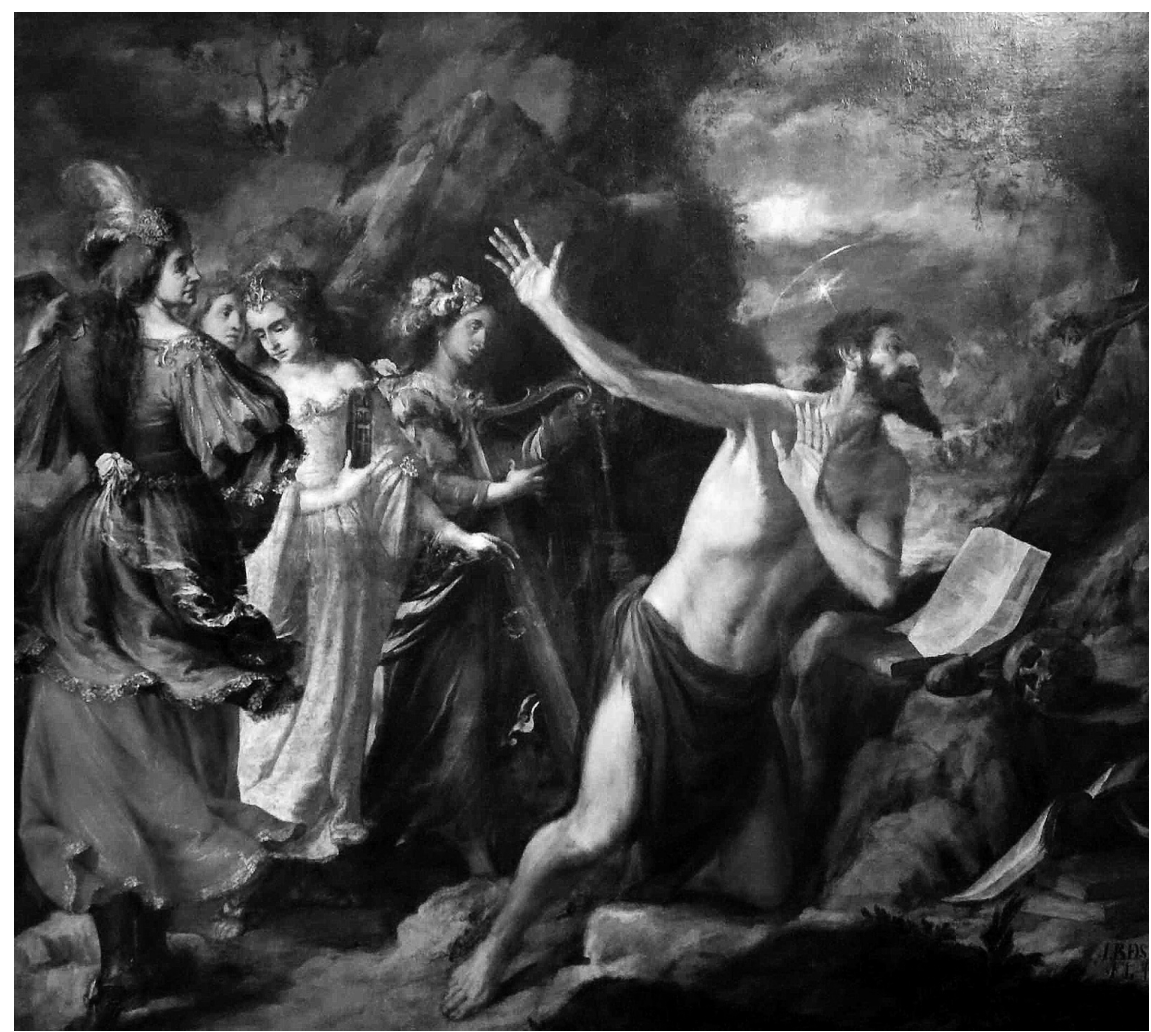

Fig. 4. Juan de Valdés Leal. Las tentaciones de san Jerónimo, 1657, Museo de BBAA de Sevilla.

que con códigos de lectura accesibles para los contemporáneos. Es el caso de Muchacha y celestina en la cárcel, c. 1650, La gallega de la moneda, 1645-1650, Cuatro figuras en un escalón, c. 1655, Mujeres en la ventana, 1670, o El hijo pródigo hace vida disoluta, 16601670. En este último, por ejemplo, sabemos de la categoría de las mujeres allí representadas porque aparecen en un banquete campestre y se dejan abrazar, mientras el protagonista bebe. Este paseo pictórico tan prudente y escaso por el mundo de la prostitución contrasta con la realidad, ya que tal profesión estaba muy generalizada en España y era incluso famosa la de ciudades como Madrid, Valencia o Sevilla (Vázquez García y Moreno Mengíbar, 1995). Entonces, ¿cómo representar el Amor? Pintando el verdadero, es decir, el casto y puro, el que no se deja llevar por la pasión desbordada que aniquila la virtud, y este amor honesto, necesario para todos, es, si cabe, más indispensable para las mujeres, porque son las depositarias del honor familiar. Hacia finales del siglo XV todavía existe una valoración de la castidad que hace que aparezcan obras como las de Pedro Berruguete, las dos tituladas Los pretendientes de la Virgen, una de 1485-1490, y otra de c. 1500. En las dos, aparece la Virgen María, vestida como una dama de la época, rodeada de sus criadas y re- 


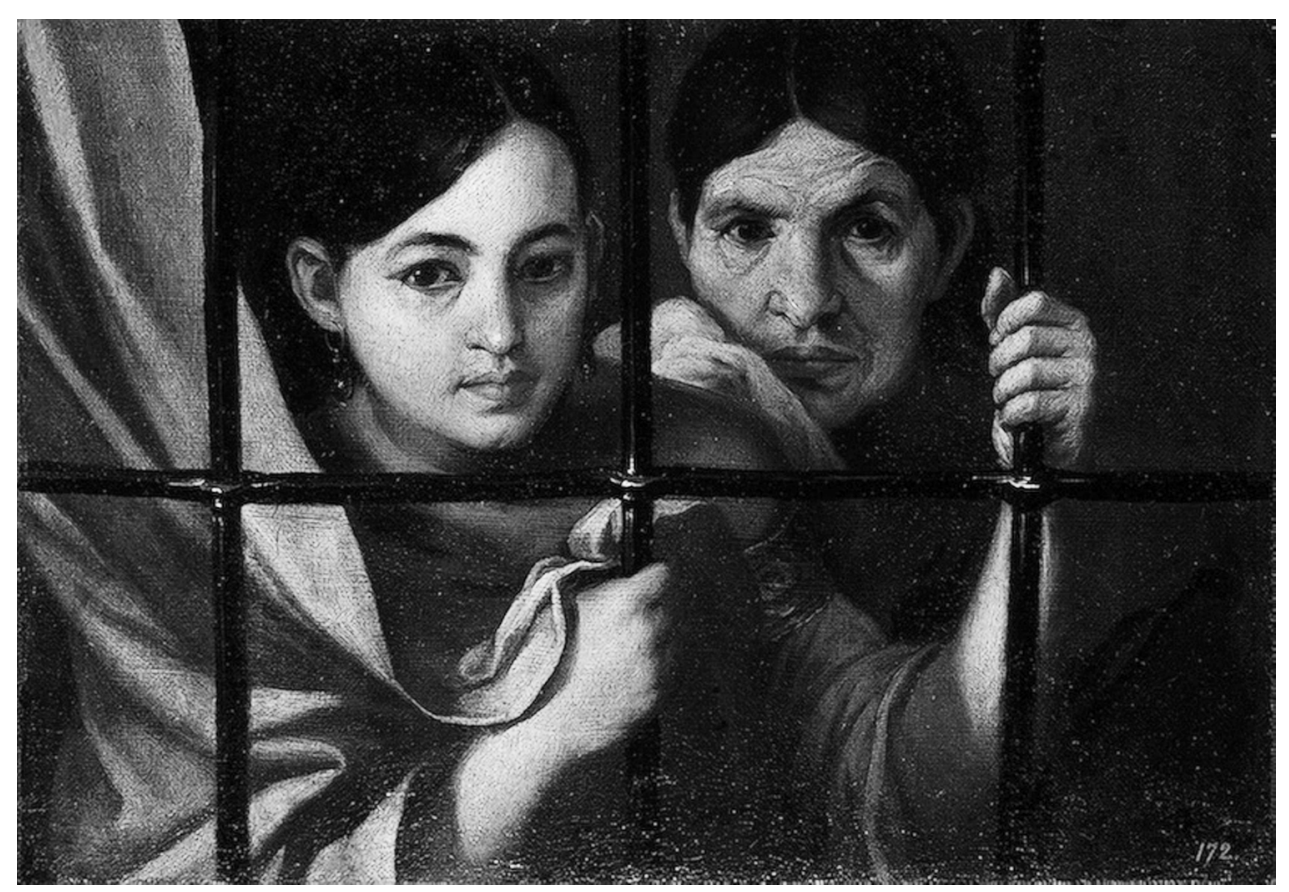

Fig. 5. Bartolomé Esteban Murillo. Muchacha y Celestina en la cárcel, c. 1650. Museo del Hermitage, San Petersburgo.

chazando a los pretendientes que le presenta un obispo. Pero, aún siendo la castidad ejemplar, el humanismo comienza a vindicar el papel del matrimonio (Morant, 2002), por tanto había que explicar cómo debía ser una doncella irreprochable que se encaminara al altar: modesta, recatada y obediente. Estos son los calificativos que le dan tratadistas como Juan de la Cerda, Juan Luis Vives, Vicente Mexía, Alonso de Andrade, fray Luis de León, Juan de Soto, Antonio de Guevara o Andrés Ferrer de Valdecebro. Quizá por ello se muestren en la pintura imágenes de Rebeca y Eliezer, como ejemplo de doncella honesta, tal y como la representa Murillo en 1652. Por lo que se refiere a la obediencia, como en todas las cualidades, no hay ninguna que se pueda comparar a la Virgen María, algunas de cuyas advocaciones, como la de la Inmaculada Concepción, cumplen las exigencias masculinas del ideal barroco de mujer. Las imágenes de la Virgen en la escena de la Anunciación son todo un exemplum del comportamiento femenino: "He aquí la esclava del Señor", responderá María al requerimiento del ángel. Incluso la escenografía del momento es significativa: un interior en el que Ella aparece, en las pinturas del XVII, no leyendo un libro, algo habitual en el siglo XV, sino trabajando afanosa en su labor de costura. Esa pura doncella se debe conservar así para poder cumplir su destino: casarse. 
Fig. 6. Sebastián López de Arteaga. Los desposorios de la Virgen, s. XVII. Museo Nacional de Méjico, Méjico D.F.

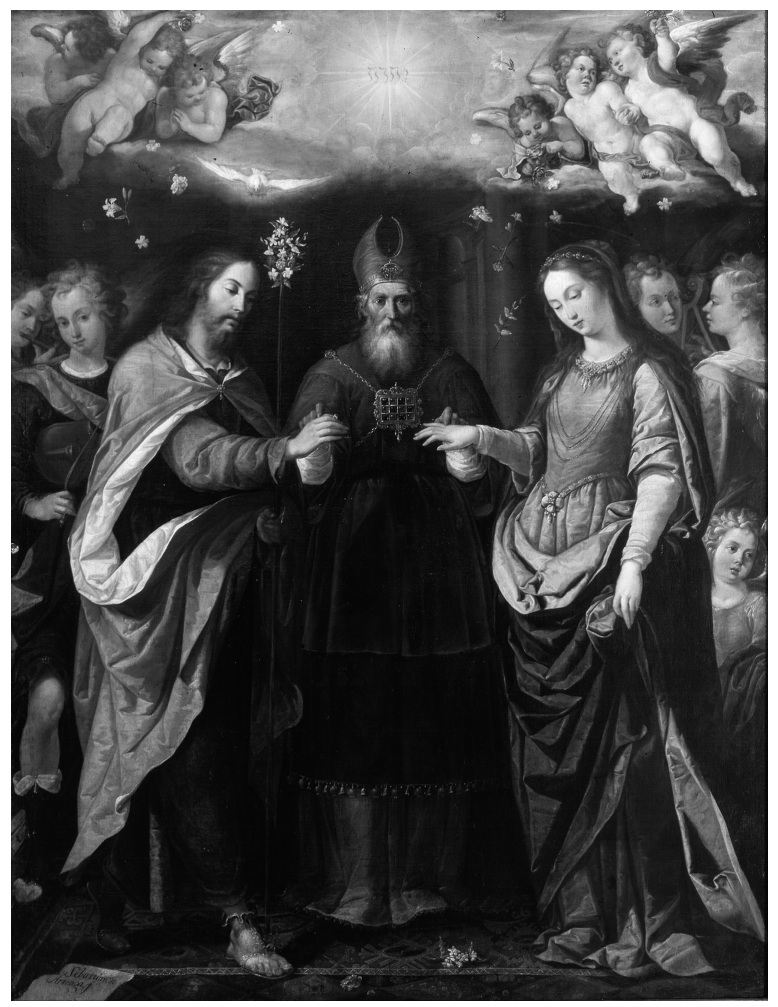

\section{CASAMIENTO POR AMORES, POCAS VECES DEJA DE PARAR EN DOLORES}

Joan de Joanes, en la segunda mitad del siglo XVI, pinta un cuadro titulado La Virgen dota a las doncellas huérfanas, en el que se muestra una obra de caridad que permitirá a esas jóvenes cumplir su honrado y necesario destino: el matrimonio. Pero este lienzo no sólo es un ejemplo más de la generosidad de la Virgen. Cuando los fieles de la época lo contemplaban, veían a María realizando una obra de misericordia del mismo rango que las que aparecen en las Bienaventuranzas evangélicas; tan importante era un buen casamiento para la mujer. En efecto, la boda, una buena boda, era uno de sus objetivos vitales, porque suponía para ella la única posibilidad de representar un papel en la sociedad (Vigil, 1994, p. 92). De la importancia del matrimonio es prueba la gran cantidad de tratados que sobre él se escriben, y en casi todos ellos se relega al matrimonio por amor ante otras consideraciones que tal vez hoy entenderíamos más prosaicas, como la dote o el linaje. También es abundante la literatura de ficción acerca de esta institución, a la que se trata a veces con cariño y otras con desafecto, cuando no con verdadero odio. Sin embargo, es muy 
significativa la escasez de retratos de matrimonios en la pintura española. En efecto, no existen obras como dos cuadros de Lorenzo Lotto, Micer Marsilio y su esposa o Marido y mujer, que son dos alegorías del matrimonio según los principios humanistas, pero tampoco hay lienzos como Matrimonio en un jardín, de Frans Hals, en el que aparece una pareja de recién casados con toda la gloria de los primeros momentos de felicidad conyugal, género que el mundo protestante repite con asiduidad, quizá porque allí se produjo un cambio en el concepto de matrimonio que formaba parte de un proceso más amplio de secularización (Goody, 2009, p. 162). Ni el simbolismo intelectual ni la imagen de la felicidad burguesa conyugal afloran en la pintura española. Son tan pocas las obras con esta iconografía, y no siempre de pintores importantes, que casi se podrían enumerar ${ }^{13}$. Ahora bien, ¿significa esto que no existen pinturas sobre el matrimonio? Sí que las hay, pero a veces esconden este asunto detrás de imágenes que revisten la unión conyugal de significados piadosos y didácticos. Un tema como el de los desposorios de la Virgen continúa siendo muy popular. En estos cuadros, el sacerdote judío aparece entre María y José y en actitud de bendecir ${ }^{14}$. El símil es evidente: si el matrimonio de la Madre de Jesucristo exigió un sacerdote, ¿cómo prescindir de él el resto de los mortales? La conversión de la unión entre un hombre y una mujer en sacramento indisoluble le dará a la jerarquía eclesiástica un enorme poder y la pintura debe difundir la importancia de la Iglesia en la institución matrimonial, ya que ella es la autoridad sancionadora. Así pues, las pinturas que se realizan en nuestro país representan lo que, desde la autoridad religiosa y desde la moral social de la época, se considera que debe ser un matrimonio. Su calidad educativa se descubre, por poco que se observe, evidente y, así, la pintura se convierte en un medio idóneo para difundir un constructo cultural según unos parámetros firmes e inflexibles que todos, sobre todo las mujeres, deben seguir y cumplir. Y este tipo de iconografías sí son muy abundantes en la pintura española.

En el relato del matrimonio ideal tiene un papel muy importante la consideración de las cualidades de la casada. Raro es el tratadista que reflexiona sobre esta institución que no fije previamente, o durante el discurso argumentativo, las virtudes que el hombre ha de buscar al elegir a su futura esposa, y siempre se le insta a que prefiera a aquella poseedora de cualidades morales, antes que a la que sólo ofrezca belleza o cuna. Tal vez por ello se representaran mujeres de la Biblia que se puedan convertir en ejemplo para las casadas. Es el caso de la prudente Abigail, de la que existen cuadros, pocos, firmados por Murillo o por Zurbarán. Sin embargo, el auténtico modelo de esposa en la pintura española va a ser la sumisa y obediente, no la mujer sensata y juiciosa que, como Abigail, es capaz de soslayar los deslices de su irreflexivo marido. Quizá era propagar un arquetipo femenino demasiado vigoroso que dejaba en mal lugar al que debía ser señor del hogar. Si estas imágenes de mujer fuerte eran arriesgadas y, por tanto, escaseaban ¿qué decir de las que eludían las normas? La mujer que engaña a su esposo es un personaje insólito en la pintura española ${ }^{15}$, ni siquiera el episodio de Cristo y la adúltera se juzga apropiado, de tal ma-

13 Francisco Pacheco, Retrato de matrimonio joven, Museo de BBAA de Sevilla, 1630. Martínez del Mazo, La familia del artista, 1665, Kunsthistorische Museum, Viena, o Familia en un jardín, 1680, Museo del Prado, que significativamente es de un pintor flamenco que se establecerá en Madrid.

14 Berruguete, Borgoña, Ribalta, Bocanegra o Murillo, por citar algunos, tienen cuadros con este tema.

15 José y la mujer de Putifar es una de las pocas representaciones del adulterio. Antonio del Castillo y Murillo la pintarán. 


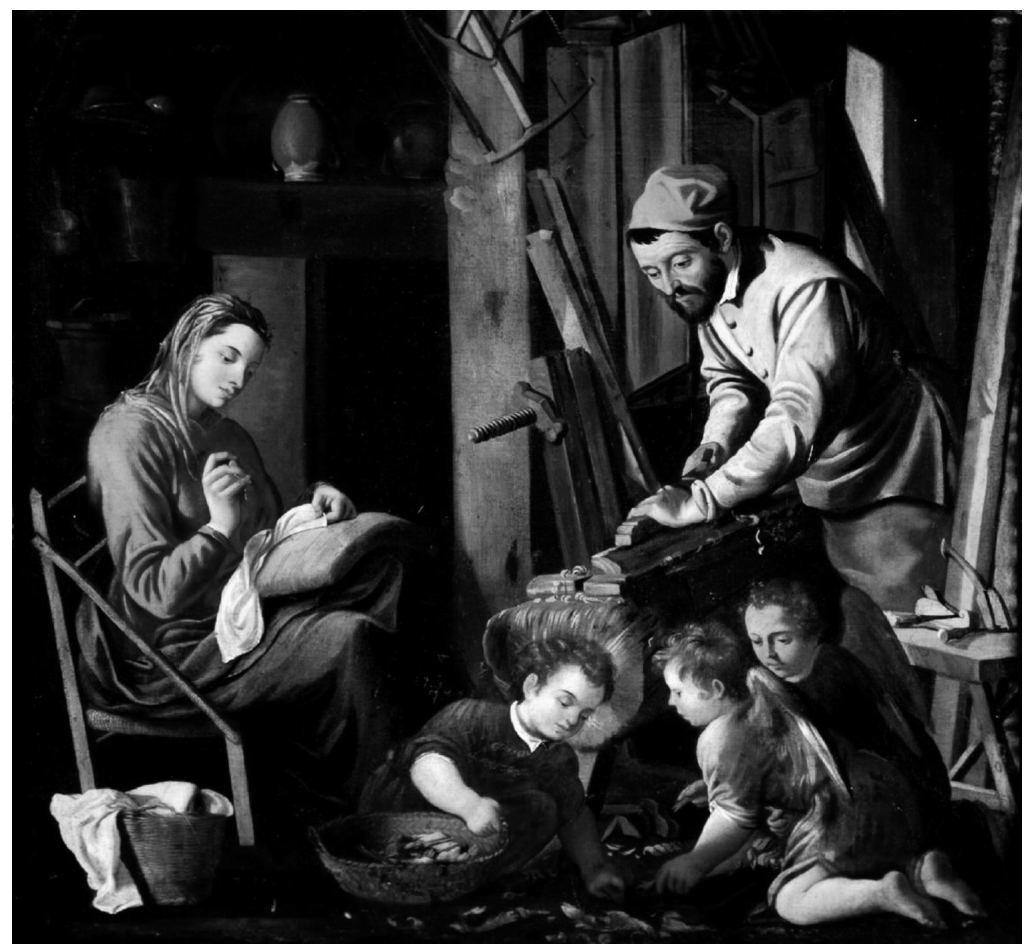

Fig. 7. Pedro Orrente (taller de). El taller de Nazareth, finales del s. XVII, Museo Lázaro Galdiano, Madrid.

nera que casi no se reproduce si no es con alguna excepción de mano extranjera, como la obra de van Dyck (Díaz Padrón, 2012), y sin embargo, en la literatura el tema del adulterio tiene una amplia representación que no hace sino retratar una realidad menos inquebrantable de lo que pudiera parecer (Arellano, 2005). Así pues, había que buscar a quien encarnara las virtudes seculares de la mujer: la pureza, la modestia y, sobre todo, la obediencia, algo que solo podía hacer la Virgen María, una vez más el referente para todas las mujeres. De esta forma, María, esposa de José, se populariza en la pintura, sobre todo la del XVII. La difusión del episodio de la huida a Egipto corresponde a esta iconografía, con María ocupada con su Hijo y José presentado como padre protector.

El Buen Amor, el amor espiritual, fue constante motivo de alabanza. En la literatura no son extraños los textos en que se ensalza este amor comparándolo con el de Cristo y su Iglesia, de tal manera que, para muchos sacerdotes, la ternura conyugal habría de imitar las relaciones entre Dios y las almas. Por encima de todo estaba el amor espiritual, y en tanto el conyugal se pareciera al místico, sería más querido, alabado y perfecto (Candau Chacón, 2003). Este acuerdo entre amor sagrado y profano, cristalizado en el matrimonio cristiano, es una exhortación de un modelo de perfección que hace el clero, sabedor, sin embargo, de 
lo complicado de su cumplimiento, de lo imposible de llevarlo a la práctica por la feligresía. Tal vez por ello, cuando la Iglesia de Roma quiera propagar estas ideas, buscará en la pintura un vehículo perfecto para conseguirlo. Sin embargo, no es fácil mostrar todas estas creencias en imágenes. Era necesario encontrar un modelo comprensible y cercano a todo tipo de espectadores. Así, la Sagrada Familia se convertirá, poco a poco, en el referente, en el ejemplo a seguir para el matrimonio cristiano. La Sagrada Familia será una de las iconografías más repetidas en la pintura española de este tiempo, profusión que no se puede deber exclusivamente a la importancia de la pintura religiosa en nuestro país. Una Sagrada Familia en la que cada uno de sus componentes ocupa un lugar en la jerarquía familiar. Es evidente que el Niño Jesús es el Hijo de Dios y su importancia es indiscutible, pero se suaviza su poder y se hace entrañable su figura. Por otro lado, se produce una evolución iconográfica en el caso de san José, mucho más joven que el que aparece en la Edad Media y ocupando un espacio preferente en la composición del cuadro. La Virgen María se suele mostrar sentada cosiendo, en actitud modesta respecto de su marido, de pie a su lado. María atiende al Niño Jesús que duerme en su cuna, o lo acoge en su regazo o le cambia la ropa, en gestos cotidianos para cualquier madre de la época. Sin embargo, cuando el Niño tiene más edad, suele estar rodeado por los brazos protectores de san José, como en un lienzo de Valdés Leal de 1673-1675. Estas representaciones contribuirán a difundir entre las mujeres la imagen de dulzura y sumisión de la esposa al esposo. Asimismo, también es frecuente ver a san José enseñando a Jesús el trabajo de la carpintería, como en la obra de Joan de Joanes, San José y el Niño. Hasta tal punto se divulgará esta iconografía en el XVII, que muchos de estos cuadros tienen por título El taller de Nazareth, como los de Juan de Roelas o Juan del Castillo. En todas estas obras, la Virgen María aparece cosiendo, y san José, trabajando, con una clara distribución de las tareas. Que estas imágenes son un claro modelo del matrimonio cristiano se puede demostrar con una pintura titulada Caballero santiaguista y su mujer, atribuida a Ribalta o a Orrente, en la que aparece una dama que interrumpe la lectura de un libro, probablemente piadoso, que deja sobre su regazo, para contemplar un cuadro que le enseña su esposo, de cuyo linaje es evidencia la cruz de Santiago que lleva en el pecho. En el lienzo que le muestra su marido, está la Virgen María hilando, mientras san José interrumpe su trabajo de carpintero para meditar. La simbología del cuadro es tan clara, que no exige mayores explicaciones. Si el propósito de su divulgación es tan evidente para el espectador actual, ¿qué decir de la doctrina que recibían, mediante este tipo de imágenes, los españoles del Renacimiento y Barroco? Otra cosa es el grado de aceptación que estos principios tuvieran.

\section{BIBLIOGRAFÍA}

ARELLANO, I. (2005): "El matrimonio en la poesía satírica y burlesca de Quevedo", en Arellano, I. y Usunáriz, J. Ma (eds.), El matrimonio en Europa y el mundo hispánico. Siglos XVI y XVII, Madrid, Visor Libros, pp. 11-26.

BROWN, J. (1988): Imágenes e ideas en la pintura española del siglo XVII, Madrid, Alianza Forma, $232 \mathrm{p}$.

BROWN, J. (1990): La edad de oro de la pintura en España, Madrid, Nerea, 338 p.

BURKE, P. (1998): Los avatares de “El cortesano". Lecturas y lectores de un texto clave del espíritu renacentista, Barcelona, Gedisa Editorial, 238 p. 
CANDAU CHACÓN, M ${ }^{\mathrm{a}}$ L. (2003): "El amor conyugal, el buen amor: Joan Estevan y sus Avisos de Casados", Studia Historica. Historia Moderna, n 25, pp. 31-349.

CERVANTES, M. (2009): Laberinto de Amor, Barcelona, Linkgua Ediciones, 152 p.

COSSÍO, M. B. (1981): El Greco, Madrid, Espasa Calpe, 302 p.

CHARTIER, R. (2002): El mundo como representación: estudios sobre historia cultural, Barcelona, Gedisa, $276 \mathrm{p}$.

DE LA PASCUA, M J J. (2005): "Las relaciones familiares. Historias de amor y conflicto", en Moránt, I. (dir.), Historia de las mujeres en España y América Latina. El mundo moderno, vol. 2, Madrid, Cátedra, 823 p.

DE LA TORRE FAZIO, J. (2009): El retrato en miniatura español bajo los reinados de Felipe II y Felipe III, Málaga, Universidad de Málaga, 278 p.

DÍAZ PADRÓN, M. (2012): Van Dyck en España, Madrid, Prensa Ibérica, 2 vols., 972 p.

FREEDBERG, D. (1999): El poder de las imágenes: estudios sobre la historia y la teoría de la respuesta, Madrid, Cátedra, $496 \mathrm{p}$.

GÁLLEGO, J. (1987): Visión y símbolos en la pintura española del siglo de oro, Madrid, Ensayos de Arte Cátedra, 290 p.

GOODY, J. (2009): La evolución de la familia y el matrimonio, Valencia, Publicacions de la Universitat de València, $309 \mathrm{p}$.

KUSCHE, M. (2004): "El caballero cristiano y su dama", en Cuadernos de arte e iconografía, tomo $13, \mathrm{n}^{\circ} 25$, pp. 3-102.

LÓPEZ CORDÓN, M M V. (1997): "Mujer, familia y matrimonio", en López Cordón, M M V. y Carbonell Esteller, M. (eds.) Historia de la mujer e historia del matrimonio, Murcia, Universidad de Murcia, pp. 13-24.

LÓPEZ TORRIJOS, R. (1995): La mitología en la pintura española del Siglo de Oro, Madrid, Cátedra, $502 \mathrm{p}$.

MARTÍNEZ-BURGOS GARCÍA, P. (1988): "El decoro. La invención de un concepto y su proyección artística", en Espacio, tiempo y forma. Serie VII, Historia del Arte, n 1, pp. 91-102.

MILÀ, Ll. del (2001): El cortesano, ed., V.J. Escartí y A. Tordera, Valencia, Biblioteca Valenciana, $678 \mathrm{p}$.

MORÁN, M. y CHECA, F. (1985): El coleccionismo en España, Madrid, Cátedra, 306 p.

MORANT, I. (2002): Discursos de la vida buena: matrimonio, mujer y sexualidad en la literatura humanista, Madrid, Cátedra, $290 \mathrm{p}$.

PORTÚS, J. (1999): Pintura y pensamiento en la España de Lope de Vega, Madrid, Nerea, 250 p.

RÍOS LLORET, R. E. (2009): “Amor, deseo y matrimonio en El cortesano de Lluís del Milá”, en Tiempos Modernos, Revista Electrónica de Historia Moderna, vol. 6, n 18, 17 p. http://bddoc. csic.es:8080/detalles.html?tabla=docu\&bd=HISTORI\&id=606198

RODRÍGUEZ G. de CEBALLOS, A. (1984): "La repercusión en España del decreto del Concilio de Trento sobre las imágenes sagradas y las censuras al Greco", en Studies in the History of Art, vol. 13, Washington, National Gallery of Art.

URQUÍZAR HERRERA, A. (2007): Coleccionismo y nobleza. Signos de distinción social en la Andalucía del Renacimiento, Madrid, Marcial Pons Historia, 229 p.

VÁZQUEZ GARCÍA, F. y MORENO MENGÍBAR, A. (1995): Poder y prostitución en Sevilla (siglos XIV al XX), Sevilla, Universidad de Sevilla, 216 p.

VIGIL, M. (1994): La vida de las mujeres en los siglos XVI y XVII, $2^{\mathrm{a}}$ ed. Madrid, Siglo XXI de España Editores, 261 p.

WALTHAUS, R. (2004): "Representaciones de Susana”, en Lobato, Mª L. y Domínguez Matito, F. (eds.), Memoria de la palabra. Actas del VI Congreso de la Asociación Internacional Siglo de Oro (Burgos-La Rioja, 2002), Madrid/Frankfurt am Main, Iberoamericana Vervuert, vol. II, pp. 1827-1839. 
